\title{
The Impact of Cultural Factors on E-Learning: Practical Teaching of Sanponna Chants among Yoruba Youths in Nigeria
}

\author{
Opoola, B.T. \\ Federal University Oye-Ekiti, Nigeria
}

\begin{abstract}
In this paper, sanponna, god of smallpox chants is one of the Yoruba peoples cultural properties. "E-learning approach was adopted by introducing the youths to use of electronic materials like video camera, android phones, and cassette tape recorders in collation of sanponna chants analyzed in this study. Few Sànpònná chants were recorded, written out and stylistically analyzed with ten Yoruba secondary school students in Nigeria. The need for this research is that attention of many Yoruba and African scholars is recently concentrated on teaching foreign oral traditions without been mindful of the inherent advantages of teaching learning and documentation of African traditional chants like Sonponna and other chants especially for the present generation of youths. Also, the positive impacts of e-learning has not been maximally utilized in the teaching and learning of Yoruba orature such as the language's numerous traditional chants. This study further strengthened the fact that African education was in existence before the advent of Arabic and European education in Nigeria and must be preserved and saved from going to extinction. The study electronically taught the youths some poetic devices employed by Sànpònná chanters which include: simile, hyperbole, onomatopoeia, irony, paradox, sarcasm, euphemism, and repetition.
\end{abstract}

Index Terms - smallpox, e-learning, programmed instruction, initiation, youth, chants, poet

\section{INTRODUCTION}

This research study is an expansion of the earlier work on Sanponna god and chants in Yoruba land in Opoola (2006).While Opoola (op cit) traced the history and practices of Sanponna, the present effort is on the teaching of Sanponna chant as one of the Yoruba poetry and chants from the traditional memorization methodology to modern day teaching technique using e-learning approach. The Yoruba people historical origin has been severally traceable to three possible sources ranging from the mythological belief of originality directly from heaven through the descending trip of Odùduwà, the Yorùbá ancestor of Ilé-Ifè in the present Òsun State, Western part of Nigeria to migration from Saudi Arabia through Egypt. Surrounding histories of the origin of Yorùbá people appears apparently contradictory so much that Johnson (1976) once submitted that:

"The origin of the Yorùbá nation is involved in obscurity"

According to Yorùbá oral tradition, the Yorùbá people history also stretches it further that Odùduwà sojourned from Mecca through Egypt and landed at Ilé-Ifẹ̀ after departure with his brothers; Gògòbírí and Kúkàwá in a 90 day journey. Odùduwà gave birth to Òkànbí the father of seven children that later settled in separate Yoruba places and towns. In analyzing these historical facts, the following critical were pointed out in ( Johnson ( op cit): points

(1.) That it appears impossible to link Yorùbás and Arabs together considering their different distant places in the world map;

(2.) That, it is equally impossible for anybody in the past to travel between Mecca in Saudi Arabia and Ilé-Ifẹ in Nigeria for only ninety (90) days,

(3.) That the fact that none of the writers in the history of Arabs made mention of the story though there appear to be resemblance in the habit, manners, architectural designs of Arabs and Yoruba people..

Jonson (o.p cit) once mentioned Sultan Bello of Sokoto reference to Yoruba people as inhabitants of (Yoruba), a province said to have originated from the remnants of the Nianoid Tribe. With this historical version, the Yoruba people were believed to have been the children of Nianoid (Lámúrúdu) who predominantly settled in West Africa to the Western Coast between Egypt and Abysinia. The seven children of Òkànbí became the founders of the following seven Yoruba kingdoms: TheOlówu of Òwu, Onísàbe of Sàbe, Alákétu of Kétu, Oba of Benin, Onípópó of Pópó, Òràngún of Ìlá, Òrànmíyàn (the Aláàfin of Òyo.The religion of the Yoruba is a bit complex. The Yorùbá major belief is that Olódùmarè-God created the world and can only be appeased through the divinities such as: god of iron,god of thunder, ancestor god, Ifá-oracle, god of small pox and several others. In the words of Jerimiye (1975), Yoruba people are of valuable sense of dedication and total ordering of everyday practical life with intense degree. The Yorùbá people have functional departmental headings in the form of divination, vocational gods, legends and myth, object of worship, principles and methods of unusual communication, places of worship designs and structures (Jemiriye op cit). 


\section{STATEMENT OF PROBLEM}

In Nigeria, like many African nations emphasis in the recent time has shifted to research works mostly on foreign languages and traditions especially English in Nigeria. This study has served as another positive attempt towards preservation of African oral renditions and Yoruba oral literature through formal educational approach.

\section{THEORETICAL FRAME AND DESIGN}

Hadge and Kress 1991 speech act theory that centers on relationship between non linguistics semantic system which accompanies speech or writing, performance and bodily texts was adopted for this paper.. The selected youths were taking to Sanponna shrine and allowed to tape record the chants as rendered by the Priests, worshippers and believers of Sanponna god in the Yoruba ancient town, Oyo. In addition, the modern oral literary analytical strategies such as isolation of simile, metaphor, alliteration in the chants were taught using the rendered sanponna stanzas. The research was designed to expose the Yoruba Youths to Sanponna renditions as traditionally presented by the real disciples of the god.

\section{REVIEW OF LITERATURE}

In forming the expected base for this research, our review of literature centers on the following concepts: E- leaning; Performance Utterances, Communication, Register and Linguistic borrowing and Yorùbá religious beliefs. E-learning is a learning system based on formalized teaching with the help of electronic resources. According to Tech Term Computer dictionary, it is an umbrella term that describes education using electronic devises and digital media. The delivery of a learning, training or educational programs by electronic means in the words of Stocley (2003) is called elearning. In other words, e learning basically boils down to learning that is facilitated and supported via information and communication technology (ict). The American Society for Training and development (ASTD) defines E-learning as a broad set of applications and processes which include web-based learning, computer based learning, virtual classrooms and digital. Opoola and Jelili (2019) once cited Elitia definition of the three speech act types succinctly thus: "speaker utter sentences with a particular meaning (locutionary act) and with a particular force (illocutionary act) in order to achieve certain effect (perlocutionary act) or hearer. In the course of driving home points, poets in Sànpònná chants do utilize these performance utterances in their utterances, phrases and stanzas in addition with physical actions to impress their audience and exhibit their prowess as custodian of knowledge of Sànpònná chants. Communication as a concept also has a primary place in the context of this study, hence its brief definition remains germane. Several definitions of communication indicate that it is an act of expression through different medium (vocal and non-vocal). In the opinion of Olubodede (1999), communication can be defined as the art and science of transmitting or exchange of ideas, information, opinion and messages between one person and another or many people. It is an art that occurs in several forms through writing, talking, non-verbal communications such as facial expression, body language or gestures. The Sànpònná chanters communicate frequently using the chants at home, at the shrine and during entertainment session, at social gatherings of members, naming, burials, wedding and other ceremonies. Creativity remains the act as the Sànpònná poets present their chants in line with whatever situation for which the chants are meant. This assertion aligns with Wikipedia 2019 discussion of Laswell's Linear communication model which says that: 'The art of communication postulates the following questions:Who Says what? In which Channel? To whom ? With what effect?" Linguistic borrowing also reflects in the skills of Sànpònná chanters and deserves brief explanation in our review of related literatures. The term "register" has been variously defined. Many literatures see register as the specialized vocabulary common to a particular trade, occupation, topic or activity. Ogundepo (2002) linked register as a lexicon that should sometimes be a synonym of 'Jargons'. Ogundepo (op.cit) defined register as the specialized or technical language part of a particular professional body or other social group. Chuka (2003) once described register thus:

"group varieties of language which lead to accurate and speedy
communication among those that know and use them but confuse those who
do not". ppl09

In the data collected on Sànpònná chants the poet made use of specialized register and words commonly used as instrument of expressing their minds on situations and particularly to entertain the audience. Some of these words are only peculiar to Sànpònná chants and could be perceived as jargons whose existence conveys meanings as in the following lines:

"Sànpònná turns wife's vagina to useless softened calabash

My god rendered the husband penis incapacitated",

Above lines are meant to express ageing and effects of small pox on whoever is unlucky to be effected by the disease irrespective of gender. Linguistic borrowing also reflects prominently in the context of this presentation. Loan words are the resultant effects of languages in contact. The relationship between the Arab Moslems and Yorùbá traditional Sànpònná religion has been expressed through the use of some carved Arabic words and noticeably prominently in Șànpọnná Chants.

The moslems

Zuhr prayer in Islam 
Arabic words in Șànpónná were restructured to suit the Yorùbá language. linguistics features: Among the resultant effects of contact between languages is the bilinguals strategy of restructuring of loaned words such as use of codeswitching and code mixing described in Opoola (1998) as two social-linguistic terms used interchangeably despite being separate though related concepts. Afolayan(1986) asserted that there could be distinction between loan words and code switching thus:

'Borrowing which occurs in code-switching is found only in the speech of Yorùbá language speakers while loan words i.e. borrowing already accepted as part of Yorùbá vocabulary are used by monolingual and bilingual Yorùbá speakers.'

In this study, Sànpònná poets made use of the linguistic varieties Arabic and Yorùbá in the same conversation. This appears to be in line with Xiaoping (2007) impression of code mixing as a socio-linguistics concept in his study of how participants of his study in local and Putonga in their daily conversation used English and China like Cantonese and Dongbeihua( Dialect in north east China). Code -mixing is the use of two or more linguistic varieties in the same conversation or interaction.

S̀̀npònná chant is a Yorùbá traditional oral poem likened to Eulogies described by Thompson Denys (1974) as:

"Only type of poem whose aim was to strengthen position of a tribal leader by celebrating his deeds in war, glorifying his ancestors or listing the allies on whom he might rely". P112.

Bringing to fore, sànpònná chant is associated with the Yorùbá god of small pox. A stylistic study of Sànpònná chants serves as another reference document in African studies and literatures. Kamsaran (1974) describes the importance of traditional documentation with respect to African literature in the following way:

No account, therefore of African literature can be adequate without some considerations of the part played in the present renaissance by literature in the indigenous language which are nearer the heartbeats of the masses than one of the adopted European languages like English, French, Portuguese and Spanish”. P5

Ogunsola (1970) described occasional festival songs in relation to Yorùbá modern days thus: In many communities in Yorùbá land, purification festivals have undergone change. It is conceivable that in the distant past perhaps a thousand year or more ago, they might have been mainly ritualistic, taking the form of symbolic action and gesture to expel evil from a community.

Teaching and analysis of Sànpònná chant is a research work carried out as an additional effort on studies inYorùbáoral poetry. Olatunde (1984) once assessed the nature of numerous Yorùbá oral literature thus:

"Much has been written on Yorùbá oral poetry, though until fairly recently emphasis has been on supplying sociological and information rather than analysis" pp.3

This piece of work on sànpònná stands out as an exemplary project with mild distance to the past of for oral poetry work devoted to seeking only the sociological information. Bamgbose (1966) once submitted that

"Traditional grammar can be seen in the work in the study of Yorùbá oral poetry".

Sànpònnáas a Yorùbá divinity had chants meant for her praises and adoration in Yorùbá land. In the Yorùbá traditional spiritual realm, Șànpọnná was a brother to Șàngó (god of thunder) and Ògún (god of iron). In connection with the migratory story that forced the Yorùbá ancestors out of Saudi Arabia and Islam, Sànpònná among his followers had direct link with Islam and the Moslems religion known among the Yorùbá people as "the religion of Moslems. The following few lines of Sànpònná chants affirmed the link between Islam and Sànpònná.

Sànpơnná, the disciple of God

It is time for Suhr (Moslem afternoon prayer)

Suhr in progress

The heaven Moslem is around

Let the worldly ones tread carefully

Obàlùfòn observes 'rakat' (Moslem prayer) with lion skin.

Sànpònná god in Yorùbá land is not restricted to Yorùbá of ancient Òyọ́ town (Òyó Àjàká). There are more Nigerians and foreigners initiated into Sànpònná cult with their carved Sànpònná symbols and shrines. Outside Nigeria, Sànpònná symbols and shrines are in Cuba, America and some other nations of the world. Therefore, this study is delineated to finding out facts about Sànpònná in the palace of Șànpònná Priest which is the historical headquarter of the god in the world, in Òyó town. Apart from briefs received on initiation and the myths about Șànpònná, attention was on few chants of the god recorded at the shrine as it has more chant tittles and unlimited number of hymns depending on the chanter and his/her chant context situation, audience, personalities and inanimate objects for which the chant must have been composed. Sànpònná followers believe that the there exists affiliation with Islamic religion. They also consider themselves as Moslems. The underlined words in one of the chants attests to this faith. Here are samples of Islam Arabic words in Sànpònná chants; See the following: 
1. AilahSuhr: Muslim afternoon prayer daily prayers.

2. Adhan -Pèrun: Moslem call to prayer

3. Moslem -Onimòle: The Moslems

4. Jiji: Temporary mosque like tent or marked ground with either bamboo or bottle Mosque.

Myth about Șànpònná makes it look like a dreaded god in Yorùbá land. It is a deity associated with smallpox especially among its non believers. Its Priests and the followers 'however, rely on his magnanimity as a savior. Among the forbidden acts as pronounced by Șànònná in relation to her temple, and doctrines are:

1. Use of whistle, modern electronic gadgets especially camera and phones: Tongue whistling around Sànpònná shrine or in the afternoon especially during dry season under bright sun is forbidden by Sanponna god The use of whistle within the temple of Sànpònná is considered to be an insult to the god. In their believe, Sànpònná used to whistle round the world during his life time and regarded same act by any other person as insult and forbidden.

2. Palm kernel oil: This is a Yorùbá liquid pomade derived from palm kernel. It is used for treatment of illness like high blood pressure and body temperature. It is also approved as traditional pomade after bath. As good and valuable it is, it should not be poured on Sànpònná symbol/statue.

3. Tobacco: Sànpònná loved smoking when he was in human form but disapproved of his followers the right to smoke cigarette or any form of tobacco. Sànpònná worshippers should not move near his shrine with tobacco or cigarette.

4. Shrine Location: Sànpònná shrine is usually located in a separate apartment with his wooden statue that increases in height as years roll by. The shrine and Sànpònná symbols accept and reject visitors and instruments as it pleases. For instance, it breaks camera lens if photograph shots of his wooden symbol is made without the consent and approval of his priests.

5. Broom (Owò): In Yorùbá land, we cut bunch of broom into small sizes of about one quarter of the normal sweeping broom for mixing soup such as green leaf, melon mixed with leaf or okro. The short broom is used for blending hot soup. The use of broom in blending soup is an abomination for Sànpònná worshippers. The priest must not eat soup blended with short broom. On no account must any follower of god of small-pox beat children or adult with bunch of broom. It is a forbidden act.

6. The Sun:Sanponna discourages man from walking under the sun in the afternoon.

Sànpònna's Relevance to Mankind According to his worshippers

SSànpònná is a healing god. In Òyó town, The Royal Majesty, the Aláàfin of Òyó has special regard for this god as a cleansing god of the land especially during the dry season. The King provides items of sacrifice to the god while the priests choose special days for festival and prayer for prevention of disaster on the Land. Sànpònná festival day is on same days with the market days of Sóró hill in Òyó (i.e. on five days interval).

1. This god is believed to be the protector of mankind from illness like smallpox, blindness, cripple/polio and mental sickness.

2. The use of items of worship like cold palm oil usually poured on Sànpònná symbol is for treating fever, headache and marrow pain. This makes the god more important among his disciples and the Yorùbá people.

3. Sànpònná is the god of justice and fair play. It uses its numerous spirits to punish traitors' thieves, adulterers, and enemies of Yorùbá kingdom. It attacks sinners with all sorts of illness and makes sinners become mentally sick, covered with smallpox or feverish to the point of death unless the confess as their sin(s) to mankind.

4. Sanponna saves mankind from the devilish attack of witches and witchcrafts. It works hand in hand with evil spirit and appeases them for forgiveness whenever they attack people

5. Sanponna assists the barren to have children. The barren parents only need to provide sugarcane, banana, groundnut, corn snacks, special open kolanut, bitter kola, cock, honey and cow breast milk. Priest of Sànpònná god in Yorùbá land lives in special palace built for him by the Aláàfin of Òyọ́. He is one of the King's high Chiefs respected in hierarchy and recognized as one of the pillars of the land because of his spiritual roles in Òyó Kingdom in cleansing the community of communicable diseases In the past, and in recognition of the traditional importance of Sànpònná, the Yoruba people used to sacrifice it with human-being. However, in the recent time, Sanponna's sacrificial items have been reduced to use of goats, cocks and other edible items. The choice of Sànpònná Priest is not by appointment or popular elevation. It is a family god. There is a particular family of long historical connection with Sànpònná since the origin of Yoruba race. Therefore, at the demise of each Baálè, the male children are subjected to the rigour of oracle consultation among whom the new Priest is spiritually chosen by Sànpònná for headship. Sànpònná priest is the chief Executive officer of the administration of Sanponna temple and activities. He should traditionally be a young man, who is knowledgeable to direct the affairs of the god. He attends to whoever needs Sànpònná's assistance in solving his/her problems and presides over initiation and it is upon him that Sànpònná spirit for prediction of happenings and curative methods and medicine for the sick ones falls. Initiation into Sànpònná traditional cult is done at any time of any day of the week. It is however generally carried out during the annual festival day. The night preceding the chosen day is for vigil. The worshipers and intending followers must sing Sànpònná praise chants, dance, dine and wine with each other till daybreak using 'bàtá' drums. The priest appears in Sànpònná regalia known for red colour. 
The night vigil is also known for special bathing which in Yorùbá land. Sànpònná Priest initiates each person into the spirit with the following materials procured separately by each intending member: water bird, vulture, fowl, pigeon, pounded yam, guinea fowl, jackal, snail, white chalk, palm wine, red pomade, white cloth, goat and palm oil. The people to be initiated must have their pubic and head hair shaved before initiation. At the completion of initiation, the accepted worshippers are collect regalia of 'red color with 'the special bead 'Sìnpònná bead' tied round the left hand ankles, of those to be initiated.

\section{Statement of the Problem}

In the past, worshippers of Sanponna used to train their children to become vast in its chants through memorization and mimicking strategies as their poets perform in traditional functions. There was no means of using electronic materials since almost every Yoruba community had no regular modern electricity supply nor other modern gadgets needed for such educational project. Also, there exists controversy over the historical linkage between the Yorùbá people and the Arabs. This more or less has created a kind of controversy since there is no known historical clause on origin of the Yorùbá people in Arabs history of origin till date though there were cases of resemblance in the habits, and some aspects of Yoruba and Arab cultures and traditions especially in areas of architectural designs on buildings, textile materials and fashion designs among others. Teaching sanponna chants with e-learning method provides the opportunity of coming across some Sànpònná chants that presented certain information on links between the Yorùbá people and Arabs. There are Sànpònná chants stanzas that elementally link the Arabs Islamic religion and with Sànpònná divinity in Yoruba land. This study therefore is set to establish the fact that with Sànpònná chants, it is evident that the origin of Yorùbá people is traceable to Saudi Arabia since Sànpònná chants consist of linking verses that relate Islam and Yorùbá traditional divinity. This paper also identified some cultural factors that need to be handled for promotion of Yoruba culture using e learning approach.

\section{PURPOSE OF THE STUDY}

The essence of this study is to demystify t he traditional believe and phobia that modern gadgets like camera phones . tape recorders and other electronic materials cannot be taken to Sanponna temple without been damaged by the superior supernatural power of the god of small pox. This traditional faith among others constitute cultural factors militating against modern means of promoting African oral literatures. Therefore teaching and stylistically working on the collated chants proved that e- learning and teaching are effective means of transferring cultural knowledge of several historical heritage in Africa to modern generations of Africans. This therefore serves as another way of saving African languages extinction sojourn. This work introduces Yoruba youths and other readers to more interesting stylistic features in Sànpònná chants. In carrying out this study, the beauty of Yorùbá linguistic features were established as embedded in how Șànpònná chants were rendered. The intent of the study also covers sourcing for how Șànpọnná chants are used as songs for traditional entertainments in areas of naming, marriage, funeral and other cultural programs especially among Òyó Yorùbá speaking of Òyó Nigerians. It is also a project that promotes the use of modern e learning devises in encouraging Yoruba youths' interest in learning the chants

\section{Methodology AND DATA COLLECTION}

Programmed instruction teaching method involving consistence reading and repletion of the chants stanza by stanza was also adopted as a reliable teaching technique. Each student privately played his/her recorded chants before the group rendition and analysis in the class. In the end of two weeks training more than eight of the students had mastered the collated chants. In other words e-learning approach assisted in promotion of individual differences in learning among the used students. There was also a direct observation of the shrine of Sànpònná and its accessories with the students involved in formal teaching of rendition and analysis of Sanponna chants. Every student tape recorded the collated chants and responses of the Priest at Sanponna temple without the priest knowledge. Android Techno phones were used by all participants in the project. At the formal class room, participants compared their recorded chants and collectively analyzed them with the leading researcher.. The Priest and his deputy were orally interviewed in gathering necessary information for the research. Also engaged for discussion were twenty five worshippers of Sànpònná among whom the selected chants were gathered. In keeping adequate and unadulterated data only the use of phone was adopted in recording the selected chants. The recorded chants were written out, translated into English and literarily analyzed by the e learning teacher in the classroom. The theoretical frame of reference adopted was Abimbola (1966) style of analysis of god of oracle chants in an expository way in which verses of Ifa were written out in Yoruba, translated into English and literarily analyzed stanza by stanza. Sànpònná Temple where his symbols and objects of sacrifice are kept was visited and video recorded with participants mobile phones. Poetic devises employed by Sànpònná poets during oral renditions were also identified and discussed in the classroom with the students. These devises include metaphor, simile, personification, hyperbole, and Onomatopoeia among others. This study took six weeks as many visitations to Sànpònná shrine were initially to no avail due to indisposition of the Priest and the Chanters. We, however witnessed the initiation of worshippers during the research period. The cultural factors identified in teaching and learning of Sanponna chants are: 1; general cultural phobia of the super natural power of god of small-pox in Yoruba land. People 
fear carrying out research work in this area of oral literature for the feeling that it is a dangerous and dreaded God. 2; Except with the support received from individual donors, unavailability of e -learning teaching materials is considered as another cultural factor that would have prevented the idea of carrying out this research work, 3; Location and limited access to the Temple and The Priest is a factor that almost hindered the achievement of the objectives of this study. It is a notable cultural factor that almost marred efforts put in place while on this empirical study. The chants analyzed include the following translated into English:

Otití, owner of warrior garment

Dress me in your attire

The large spiritual garment owner

Father of the youth and Moslems

He, on whose head crown fits

The man with bead fitted neck

The Sànpònná priest with lágídigba bead

The boastful one with the commanding tune

The mother's sacrifice is smaller in quantity than his father's sacrifice

He that refuses sacrificing the spirit shall pay dearly

You failed to call me Moslem?

Since I am not with rosary?

Moslems are no longer faithful to god

A submissive one feeds well

My holy god, accept him

I've been ordered, to carry masquerade

I accepted

I was ordered to fast

My fast stands at sixteen

To go for transits animal

That was how the Moslem was caught

The faithful Moslems

Remains blessed and feed fat

The unfaithful Moslems

The unrepentant youths

The holy father, please hear them

The Youth that listens to me

Agbada the son of Ayeni

The unlimited palace wealth

Alàbi's house masquerade provides it for me

The numerous children in Àlàbi palace

Accept my request for them

The Youth children of Iyálòde

Who is the Youthful father of all Moslems

The mighty servant descendant of palm wine drinker

The junior brother of Ògún Moslem

I have customers for native medicine

I have customers for palmwine

Entered into rebellion with palmwine tapper

If you negotiate with palm wine seller

lt's time for suhr(Moslem prayer) the king of suhr

That is how wealth filled Islam

Agbada the son of Ayeni

The great Moslem that pray with the lion skin

The sermon Priest is most qualified to snatch my wife

The greatest masquerade likened to Adégbàyi, the hunter

Àkànni, on my kneel I hung the bag

In standing position, my hand could not reach same bag

I suspect the witches at play

People planted their seed on the boundary

Adégba the great planted his own in the open space

Should we oblige, Oya(goddess of river)

Oya used a basketful of okro (ilá)

The Queen with one hundred and twenty boxes 
As servant rests on the mat in the morning, so also are the servants(Ìwòfà's)

The masters son also reclines

Elders on tour of Òrì̀̀ world

Never clean the statue with cotton leave,

Lattan Leaves scratchiness

The problem with the spirit goes with it

The spirit problem deserves sacrifice

The great masquerade that speaks like human being

Father, the war-lord of heaven

The messenger of death,

The lord, You are a great man

You turned bride's vagina to flatten calabash,

Ewéjé, my husband, you turned husband penis into lifeless rod,

You turned old woman's vagina into moisture

You visited your farm behind Dàáké

Ewédimó, my husband, we felt it is a dried wood

Touch Șànpònná statue with axe and hear the voices of the witches,

Touch Olúbáyòdé with axe and hear the voice of heaven,

The great masquerade with cloth attached leave,

Sìnpònná is the lord of open junction

Should you descend on the head

The creator, take not my own

Should you take the neck

The voice shaker

The great masquerade with clothe attached leave

The owner of knowledge

Expose me to knowledge with your axe,

Lord,you are too great a man

You provide wealth without intimidation

Sànpònná, the open junction lord

On Koláwolé's arrival ,I became strong

The war-lord with two he-goats in the same trouser mouth,

Before the trouser warns out

May god provide us additional two

Thank god, the lágídigba(beeds) my father

The spirit that saves his children from thebarren world

You rear lonely sheep,

He that needs children must appease to the spirits

As small as pounded yam

Olọlá, the war-lord will not eat cornmealie(èkotútù)

Epè,the war-lord will reject cornmealie

Sacrifice for the head with matured items

Throw away the immature ones

Aponímoró descendant of gàngàngúdú

Alágúdú man, the great

Should my mother accepts witches,

As daughter, I accept chalk (white witches)

\section{Poetic Devices EMPloyed By of ȘÀn Pò̀ N Á Chants PoETS}

Linguistics is the scientific study of languages. It exposes languages in contact and change with their resultant effects. Language is employed in both modern traditional oral and written literatures. Sànpònná chants fall within Yorùbá people notable oral literatures for traditional worships, entertainments and feasting. The few collected chants show the beauty of the Yorùbá language particularly when they are stylistically analyzed sourcing for the following poetic devices: simile, metaphor, personification hyperbole, onomatopoeia, irony, paradox, sarcasm euphemism, repetition.

1. Simile: It is the act of direct comparison and a regular concept employed by Sànpònná poets in expressing themselves. Nwasambe and Agbade (2005) defined simile as:

an expression that describes something by comparing it with something else using the words: 'as', 'like', 'as if', 'as though', 'as, 'as....so'. This is direct comparison between two objects that shares at least one quality (p.5) 
In the Sànpònná chant, the following comparisons were made using simile devise.

The greatest masquerade like Adégbàyi, the hunter.

The great masquerade that speaks like human being

2. Metaphor: Metaphoric expressions are for comparison of personalities, event or things in an indirect manner. The Sànpònná poets and chants analyzed also applied this devise in lines 31, 67, and 70

The unlimited palace wealth

Turns bride's vagina to flatten calabash

Turns bridegroom penis to lifeless rod

3. Personification: This devise gives the attribute of life and understanding to inanimate objects. It poses non-living things as if capable of playing the roles of animals or human being. In Sànpònná chant, the following were observed in lines 84, 90 and 95.

$\begin{array}{lll}\text { Sànpònná, the open junction lord } & \ldots . . . & 84 \\ \text { The spirit that saves his children from the barren } & & \\ \text { world } & \ldots \ldots & 90 \\ \text { Olólà, the war-lord will not eat cornmeal } & \ldots . . . & 95\end{array}$

4. Hyperbole: Among the devises employed by Sànpònná poets is hyperbole in providing exaggeration. It has to do with exaggerated statements. In the studied chants, the poet made use of exaggerated statements in praising Sànpònná and her priest. See lines 1, 3, 8, 32 and 73.

Otití, owner of medicinal garment

The large spiritual garment owner

$\ldots \ldots 1$
$\ldots \ldots .3$
$\ldots \ldots . .18$
$\ldots \ldots .32$
$\ldots . .73$

$\begin{array}{ll}\text { The boastful one with commanding tune } & \ldots \ldots .8 \\ \text { The unlimited palace wealth } & \ldots \ldots .32\end{array}$

Touch Olúbáyòde with axe and hear the witches voices $\quad$..........73

5. Onomatopoeia: This has to do with correlation between words whose sounds suggest their meaning. Appraised Sànpònná chants have fewer examples of words whose sounds suggest meaning. Lines 66 and 67 provide good illustration of onomatopoeia:

You changed bride's vagina into wide open calabash

You rendered the husband's penis into lifeless rod

The words 'kólòbó'(wide opened calabash) and 'robọdu'(lifeless rod) suggest their meaning as applied in the contexts of lines 65 and 66 .

6. Irony:This has to do with expression meant to be opposite of poet's intention. In fact, such words or expressions are satiric. We discovered that Sànpònná priest presented a number of ironical expressions particularly where it links Sànpònná with Islamic religion in lines 11-18

You failed to call me Moslem

Since I am not with rosary

Moslems are no longer faithful to god

A submissive one feeds well

I've been ordered, to carry masquerade

I accepted

I was directed to fast

My fast stands at sixteen

7. Paradox: A statement is termed paradox if it appears as contradiction at the surface level but have some truths on closer scrutiny.Lines 11-19 also fixed appropriately as paradoxical statements. A close observation of Șànpònná mode of worship and discipline shows resemblances to Islamic religion doctrines. Sànpònná worshippers observe fasting just as it is done in Islam though differently in number of days i.e (10\&30). Sànpònná forbids drinking of alcohol as it is forbidden in Islam.

$\begin{array}{lll}\text { 'You failed to recognize (call) me as Moslem' } & \ldots . . . & 11 \\ \text { 'Since I do not have rosary' } & \ldots . . . & 12\end{array}$

8. Sarcasm: Expressions under this category are though irony but used with contempt. It is a direct ridicule to show annoyance', (21). He provided the following example:

"'A flight was delayed for two hours. Somebody then remarks: "Good and efficient service".

Lines 41- 45 of the analyzed Sànpònná chants sounded sarcastic in the analyzed chants below:

I have customer for palm wine $\quad$...... 40

Entered a rebel with palm wine tapper $\quad$...... 41

If you negotiate with palm wine seller $\quad$...... 42

lt's time for suhr(Moslem prayer) the king of suhr $\quad$..... 43

That is how wealth filled Islam $\quad \ldots \ldots . .43$

Agbada the son of Ayeni $\quad \ldots \ldots . \quad 44$

The great Moslem that pray with the lion skin $\quad$..... 45 
9. Euphemism: When a figure of speech presents an unpleasant fact in a pleasant way to cover its real nature, then euphemism is used as a stylistic and poetic devise. e.g.

'He politely sent his father out of his house",

The following lines in Sìnpònná chants are examples of euphemism statements.

'The sermon presenter is the only most qualified person to snatch my wife'

'People planted their seeds on the farm boundaries'

…. 46

'Adégbà, Sànpònná,the great, planted hissed in the open space'

..... 51

...... 52

10. Repetition: When a word, phrase or idea is expressed more than once by a poet, repetition has taken place. Some repetitions are 'partial' while others are 'full'. The essence of repetition is to lay emphasis .In the appraised Sànpònná chants, the poet applied repetitive strategy to draw home some salient messages as in lines 21 and 22 and 39 and 40.

That was how the Moslem was caught $\quad \ldots \ldots \quad 21$

That was how the Moslem was caught $\quad \ldots . . \quad 22$

I have customers' for native medicine $\quad$..... $\quad 39$

I have customers' for palm wine

…. 40

Touch the statue with axe and hear the voice of

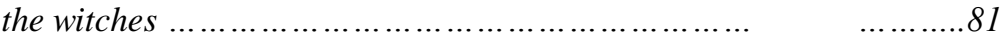

Touch the statue with axe and hear the voice

From heaven .82

\section{RECOMMENDATIONS}

An empirical and stylistically study of Sànpònná and its chants have taken us practically to historical background of one of the African traditional gods in Yorùbá land and use of e-learning combined with programmed instruction teaching methods. This can be adopted in further research works on African orature. Having visited the temple, interviewed the priest and other worshippers of Sànpònná, recorded and analyzed few of Sànpònná chants, another additional research opportunity has been opened in the study of Yorùbá and Africa traditional religion onthe beauty of the linguistic properties and interest in the Yorùbá traditional religious chants. While we are not ruling out past studies on Sànpònná god that may have been in existence, this study is adding to the crop of literary attention on the god of small pox in Yorùbá land. The following points deserve special scholastic attention:

1. Sànpònná god had its own contributions to peace and healthy condition of the environment going by Africans traditional beliefs and religion. Therefore, protecting the existing natural artifact of Sànpònná will be in the interest of Nigeria and Yorùbá nation. The National commission for Museum and National Emolument in Nigeria therefore needs to enlist Șànpònná shrines as Tourist Centre.

2. Sànpònná chant is one of the dying Africa oral poetry. Nigerian Government needs to encourage more research studiesin this area and sponsor more publications on Sànpònná and other African religion chants if the old poets will not be allowed to die with their wisdom and traditional talents. This research work has provided a kind of preservation of one of the Africans traditional poems with its collection of chants from the agreed ones since the younger folks appear not too keen again in African traditional chants and songs.

3. Institutes of Africans studies, and Departments of Linguistics and African languages in Nigerian Universities are also encouraged to promote studies in African languages and traditional religions. More Student's projects and term papers are to be encouraged on Șànpọnná chants particularly beyond the present coverage (Ò̀yó)

4. A survey of priests of African religions is inevitable with the desire to provide them with positive incentives. In the course of this research, it was discovered that many foreigners especially Americans and Cuba people are daily coming to Sànpònná Temple in Òyófor research investigation. This work has opened more sensitization for stakeholders in African 'studies to re-focus good attention to this Yorùbá deity.

5. Yoruba language teachers should be specially trained on the use of electronic devises in the teaching of Yoruba oral traditional literature. This will assist in no small way in the documentation of traditional chants and others.

\section{CONCLUSION}

In this study, we have physically visited Șànpònná Temple at Àgùrè, Òyó where we video recorded the chant as rendered by the disciples of the god of small-pox in Africa. Stylistics devises such as simile, metaphor, hyperbole, euphemism, sarcasm and other were identified as features of Sànpònná chants being literarily appreciated while teaching the selected students in the formal classroom setting using e-learning and programmed instruction techniques. Recommendations for preservation of the chants, Sànpònná Temple and priests were proposed hoping that their timely usage will add to protection of African Artifacts, religions and oral poetry.

\section{REFERENCES}

[1] Abimbola, W. (1976). An exposition of ifa literary corpus, Ibadan: University Press. 
[2] Afolayan A. (1986). Yoruba language and literature. Week-end Seminar on Yoruba language and literature. Ile Ife: University Press.

[3] Austin J.L. (1962). How to do things with words. Massacussetts: Harvard University Press.

[4] Bamgbose,A. (1966). A Grammar of Yoruba ,Cambridge: University Press.

[5] Chukla, R. (2005). Dictionary of Education New Delhi: APH publishing corporation.

[6] Daramola. (2003). Introduction to Mass Communication, Lagos: Ruthann press Ltd To.

[7] Derek Stockley. (2003). E-learning definition. www.derekstockley.com (retrieved on the 23rd of August 2018).

[8] Hadge and Kress. (1991). Socio semiotics. Cambridge: Polity Press.

[9] Jemiriye, T. (1998). The Yoruba god and gods. Ado Ekiti: Petoa Educational publishers.

[10] Johnson, S. (1976). The history of the Yorubas. Cambridge: Library Collection, African studies.

[11] Kamsaran, J.A. (1974). New approaches to African Literature, Ibadan: University Press.

[12] Kayode J.O. (1984). Understanding African Traditional Religion, Ile Ife.: University Press.

[13] Nwachukwu, A; Oyeleye, L., Uwasamba. (2005). Literature in English 2006-2010 WASSCE, Ibadan: University Press.

[14] Nwachukwu-Agbada J. (2005). The forbidden fruit. Ibadan,: University Press plc.

[15] Ogunba, Oyin. (1982). Yoruba Occasional festival Songs in Yoruba Language and literature, Ibadan: University Press.

[16] Ogundepo A.O. (2012). Essential of communication Skills in English Language. Ibadan: God's power ventures

[17] Olatunde O. (1984). Features of Yoruba Oral Poetry. Ibadan: University Press.

[18] Olubodede. (1999). Boosting your career, Development. Lagos: Mak communication press.

[19] Opoola, B.T. (1998). Nigerian Languages For Pre-NC,. Makurdi: Onaivi publisher.

[20] Opoola,B.T. (2006). An empirical and stylistic study of Sanponna chants in Yorubaland. In A.F Opoola., ed. Historical and cultural background of the immediate environment. Oyo: Omooje Printing press.

[21] Opoola, B .T. (1999). Language in contact. A case study of the influence of English on discourses of selected Yoruba - English bilinguals. Unpublished Ph.D dissertation University of Calabar.

[22] Opoola, B. T, and Jelili. (2019). A Sociolinguistics consideration of Intermediation in greetings discourses among the Yoruba of south western Nigeria. Ekpoma Journal of Language and Literary studies. Vol 12 no 1.

[23] Thompson, D. (1974). The uses of poetry .Cambridge: University Press.

[24] Wikipedia. (2019). Laswell model of communication. (en.wikipedia.org.wiki>laswell-of-communication) retrieved on the 9th of December, 2019.

[25] Xiaoping, J. (2017). A case study of code-switching in a city of East China. Ethical lingua: Journal of Language teaching and literature 4.1., 1-1.

Opoola, Bolanle Tajudeen was born in Oyo, Oyo state Nigeria. He has his BA, MA, and Ph.D in Applied Linguistics of University of Calabar. He is an Associate Professor of Linguistics at The Federal University Oye Ekiti, Nigeria and had published several books in Linguistics and Language teaching and learning. 